\title{
Characteristics of Palestinian Economy and It's Competitive Advantage of Porter's Theory and Diamond Model
}

\author{
Orobah Ali Barghouthi ${ }^{1}$ \\ ${ }^{1}$ Faculty of Business and Economics, Department of Banking \& Finance, Alquds University, Abu Dis, Palestine \\ Correspondence: Faculty of Business and Economics, Department of Banking \& Finance, Alquds University, \\ Abu Dis, Palestine.E-mail: obargothi@hotmail.com
}

Received: November 22, 2017

Accepted: November 26, 2017

Online Published: November 30, 2017

\begin{abstract}
The study focused on the advancing the competitive advantage of Palestine. The Palestine Investment Fund as government body in enhancing competitive advantage of Palestinian economy, the study sought to answer the research aim.
\end{abstract}

Keywords: Palestinian Economy, Porter's Theory, Diamond Model.

\section{Introduction}

Specify the main characteristics of Palestinian economy and its competitive advantage in the period from the occupation of Palestinian territories in 1967 until the Oslo agreement that established the Palestinian Authority in 1994

In Palestine, until the advent of the peace process import substitution was almost the only outlet for industrial goal setting. However, protection was impossible because of forced opening of the economy for Israeli products without restriction, however, the custom union with Israel, which existed since 1967, allowed free trade largely in one direction. By denying Palestinians the opportunity to export to Israel, it deprived the Palestinian firms from the incentives to produce for export rather than for import substitution, and thus benefit from the opportunity to upgrade their productivity to match Israeli standards.

With the peace process and the signing of Paris Economic Protocol, which largely sought to correct the asymmetry in trade relations, a new horizon appeared to open, but its still fruit with difficulty as although Palestinian manufacturing and agricultural exports, have theoretical duty-free access to the Israeli market, there are still considerable non-tariff restrictions, which limit access, not to mention the unpredictable total closure, which is frequently imposed, ostensibly for security reasons, but in reality as a practice of collective punishment.

The faithful implementation of the peace agreements, and a just outcome of the final status negotiations, which fulfills the aspirations of the Palestinians of the Palestinians, to attain complete statehood and regain control over their homeland and resources. This will poise the Palestinian economy to enter investment and innovation driven stage, characterized by the ability of the economy and its firms, to invest aggressively in:

- Upgrading labor skills to increase the pool of technical personnel while maintaining relatively low wages. 
- Creation of modern of modern infrastructure.

- Construction of new, well-organized, and regularly large-scale services, prepared with best available expertise.

- Acquisition of overseas manufactured goods and process technology through licenses, joint ventures.

- At this hoped for "investment - driven stage ":

- Home demand will remain largely unsophisticated. Palestinian firms would still compete in the relatively standardized, price- sensitive segments of the market, and undertake product designs that reflect Israeli, neighboring Arab and foreign market needs.

- Production will remain solely based on foreign technology, foreign equipment, and largely foreign components. This technology is of the type where accumulated experience and highly specialized human resources are not required; usually some firms from other nations must be under competitive stress to cause them to be willing to sell technology.

- Candidate industries are likely to be those with considerable scale economics and capital requirements but still large labor cost component, standardized products, low service content, process and product technology that is readily transferable and obtainable from several sources.

- Opportunities for the Palestinian firms to gain competitive advantage are predicated on their willingness to invest in modern assets in mature industries where foreign competitors' plants may well be obsolete. Already, there is at least one example of the Jordanian manufacturer of paper rolls whose modern plant enabled him to compete successfully in the Israeli market against products of obsolete Israeli plants.

If the Palestinians are to succeed in emulating the investment-driven model they have to develop a national action plan for grafting the determinants of competitive advantages in the economy at all levels. The national action plan for competitive advantage reflected national consensus, in the since of sustained commitment, shared by the general public,

As will as the politicians in a government that favors long term economic growth and future prosperity. Over consumption and fair distribution in the short term, and so undertakes the hardship and sacrifices needed, for mobilizing the necessary savings, and channeling them in to productive investment.

The political culture should be such a favor investment in the improvement of factor quality, in physical and institutional infrastructure that reduces transactions cost, and improve productivity all- around. At the same time the government should be backed by a strong democratic public support so that it cans standup to political pressures by special interests that try to prolong protection or to seek favors that impair competition.

It is judgment of Porter that "some developing countries still make the ump in to this phase, during post war phase, just Japan and more lately Korea have succeeded. Spain, Taiwan, Singapore, Hong Kong, to less significant extent Brazil is viewing symbols of making it happen this stage. "(1990, p.552)

The national action plan for competitive advantage will be guided by the set of concepts and analytic tools, which Porter calls the new Paradigm of Competitiveness including his so- called Diamond of National Advantage.

Within the context of this theory, the countries level of income the ultimate economic goal in a county is determined by the efficiency by which the countries capital and labor are in use. efficiency is defined as the price of production created through a unit of labor or a unit of capital, it depends both on the value of products and services as well as the effectiveness with which they are produced, it determines wages and the return of capital, the tow major factors are sources of income, increases productivity depend on the ability to create and 
improve competitive advantage.

The ability of nations to compete depends on their ability to improve productivity, the competitive advantage of industry ids dynamic and depends on the ability of industry to improve its products, providing new features, and adopt superior production process and more responsive services; this is parallel with traditional concept of competitive, which is based on cost prices.

The main principles of the new competitiveness parallel may by summarize as follows:

- Not nations, but Corporations and firms are on the front line on the global completions.

- The productivity does not consider a function of what industries that the country has to compete with but the issue is on the way firms compete in the industries it has.

- Competitive advantage can be achieved and sustained through continues innovations and improving the productive capacities and financial and corporate strategies

- The innovation process and upgrading is inherently local, companies need environment that assist them in evolving and sustaining the capability to innovate quickly in knowledge and approaches and to do so in the appropriate direction

- Competitive advantage outcome from an efficient mixture of corporate strategies and nation environment that is supportive of corporate strategies. Nations remain important.

2. Appropriate strategies of the companies measure competitive advantage against the best world wild competitor

The environment in the country fosters gain in competitive advantage when it supports rapid accumulation of highly specialized skills and assets, allow better information, insight of products and in process needs, and put the company under pressure to invest and innovate.

The new paradigm explains the performance of the industry by analysis the forces that affect the capability of the institutions within the business to compete internationally and maintain the industries strategies situations, these factors represent the contributions of country that independently and on the organization level compose the playing field that each nation provided for its industries, between them they are determinate that create general atmosphere on which firms are born and be trained how to compete, in which they can pursue consistent improvement, innovation and upgrading in particular field and develop more sophisticated competitive advantage, together they form an active scheme that is more important than its parts, by the time they tend to equally reinforcing or equally undermining.

The determines of national competition advantage are dynamic circumstances, demand circumstances, connected and supporting industries and corporate strategies, construction, competition.

Specify the main characteristics of Palestinian economy and its competitive advantage in the period from 1994-2012 in light of the application of Porter's Theory and Diamond in Competitive Advantage

PIF has contributed extensively to the Palestinian national economy through a number of ways that can be summarized as follows:

First: PIF's contribution to the GDP through creating economic value added where PIF's operational and investment expenditures have contributed us $\$ 495$ million to the Palestinian economy, this Contribution comprises; Wataniya mobile contribution of \$125 million, Amaar contribution of \$94 million, the Palestine Commercial services Company contribution of $\$ 112$ million, and the loan Guarantee Facility contribution of $\$ 114$ million, during the period between 2007 to 2011; with an Average contribution of us $\$ 123$ million annually.

In addition, PIF's contribution in terms of taxes paid to the Palestinian Authority (income and value added 
taxes), amounted to $\$ 52$ million over the past two years, representing 5.5\% of the total tax revenues of the Palestinian national Authority for these two years. Which makes PIF's total contribution to the Palestinian Authority's revenues between 2003 and 2011 over $\$ 700$ million, including \$653.6 million in dividends, and $\$ 51.7$ million in taxes?

Second: PIF's contribution in job creation where PIF and its subsidiaries have contributed to the creation of about 10,000 direct and indirect job opportunities between 2008 - 2011 in various sectors including real estate, telecommunications, and small and medium enterprises, representing $1.4 \%$ of total employment in Palestine, and about $2 \%$ of private sector employment. These new jobs have contributed to the reduction of unemployment, while the related wages and salaries have stimulated the economy through the spending multiplier, which reaches 4 in Palestine.

Third: PIF's contribution to the Palestinian Authority's budget in the form of dividends, which reached over $\$ 653$ million for the years 2003 to 2011, at an average of \$72 million annually, and accounts for $14 \%$ of the average domestic revenues for the same period. This contribution has been critical to the sustainability of the Palestinian Authority's finances, especially in periods of donor aid disruptions.

All in all, PIF's contribution to the Palestinian economy is multidimensional and involves supporting the private sector through various initiatives that bring in additional capital, knowledge, expertise, infrastructure and other sources of value to the Palestinian economy including; job creation; tax and dividend distributions to the Palestinian Authority.

To further explain the findings on the status of Palestine economy, Orobah explained,

"When we talk about economic policies in Palestine the main issue is with whom Palestine will build its integrations with Arab world, with Europe, with United States or with Israel. For integrating with Arab world its very romantic solution but it will not work from profitability point of view as Palestinian products don't have competitive advantage in Arab world markets, its prices will be high for many reasons as high value added tax, high labor cost and high transportation cost.

In formulating our relationship with Israel we have two options, custom union as now in which we adopt same value added tax of Israel which is considered very high if compared with this applied in Arab world, or separating from custom system of Israel going toward free trade area in which we have separated value added rate, with a lot of suspicion that Israeli people will allow Palestinians to import goods and services with lower value added tax that applied in Israel, so Israeli people will by the cheaper one from Palestinian territories."

He further discussed that custom trade and free trade area as choices to advance the development of Palestinian economy is not easy at all. Orobah said,

"Its question not easy at all to be answered according to many considerations, political, economic and cost considerations, during six workshops I attended with European commission that discussed the shape of future relationship between Palestine and Israel, custom union or relationship, there are two extreme opinions, one with free trade area which means separating from Israel then independent t custom system, the other one, my opinion, the rational one that we couldn't separate, Israel will not allow in addition to the difficulties we will face in building dependent trade regime from Israel as we don't have borders and free circulation in the Palestinian territories between cities, Israel handy cap movement between Palestinian cities which increase the prices according to higher transportation.

In the 1998 study of Michael Porter of Palestinian economy, he found out things work if these industries exist on border between Palestine and Israel under the umbrella of free trade zone, many people refused for political reasons." 
In the study of Porter of the Palestinian economy in 1998, he distinguished the four stages in the development of a nation's competitive advantage. The first stage is factor-driven. In this stage, the basic factors of production are the sources of the advantage. In that same year, Porter identified Palestine being in this stage; it is starting in the development process. There are a lot of impediments in its economy including interlocking monetary and financial system with Israel and Jordan, custom duty collections go to Israel and the lack of a central banking system.

\section{Conclusion}

Porter identified that furniture; food processing, wearing apparel and textile industry, garment industry, pharmaceutical industry, stone cutting, shaping \& finishing industry, olive oil industry, and tourism industry cluster are the main economic blocks.

This year 2013 after applying Porter's ideology of development and advancing national competitive advantage factors, Dr. Orobah observed that only the tourism industry achieved progress and there are big numbers of agreements for tourism. Palestine lost the chance to succeed, solve the problem of thousands of Palestinian labor and create job opportunities because of the interference of political and economic events in the area.

Identify the role of $\mathrm{PiF}$ in enhancing the investments, building the competitive advantage of Palestinian economy in light of Porter's Theory and Diamond in Competitive Advantage

The new paradigm of competitiveness is determined by the productivity with which the country's labor and capital are employed. (Porter, 1998)

This new paradigm has defined the value of output produced by unit of labor or capital. Therefore the income derived from these inputs which are wages and return on capital should increase as productivity increases. If this happens then the ability to create and upgrade competitive advantage follows.

In the same literature, Porter emphasized that a nation's ability to compete depends on their ability to improve productivity.

Porter stated that each nation should cover certain factors of the Diamond model, which basically determined the competitiveness of the firms constituting the nations, and as a result the nation itself. For Palestine which is considered strongly in the investment stage for the major investments made by the PIF since the year 2003. In this model, there are four main determinants of national competitive advantage:

- Factor conditions;

- Demand;

- Related and supported industries; and

- Firm strategy, structure, and rivalry.

These determinants are used to assess the different programs under each sector of the Palestine Investment Fund based on 2011 data.

The Palestine Investment Fund (PIF) aims to strengthen the local economy through key strategic investments, while maximizing long-run returns for its ultimate shareholder; the people of Palestine. PIF has US $\$ 1000$ million of assets under management and is headquartered in Ramallah, Palestine. PIF's investment focus includes the following strategic sectors: real estate, hospitality, finance, industry, telecommunications, power \& energy.

\section{References}

Porter, M. E., (1996). What is Strategy?. Harvard Business Review, Issue November-December, pp. 2-22.

Porter, M. E., (2008). The Five Competitive Forces That Shape Strategy. Harvard Business Review, Issue January, pp. 23-41. 
Ranchhod, H. B. S. a. A., (2006). Competitive advantage of a nation in the global arena: a quantitative advancement to Porter's diamond applied to the UK, USA and BRIC nations. Strategic Change, 15(September-October), pp. 283-294.

Ricardo, D., (1951). On the Principles of Political Economy and Taxation. Cambridge: Cambridge University Press.

Smith, A., (1904). The Wealth of Nations. 5th ed. London: Methuen and Company, Ltd..

Tzu, S., (2005). The Art of War by Sun Tzu. Special Edition ed. El Paso : El Paso Norte Press.

Van Den Bosch, F. A. \& Van Prooijen, A. A., (1992). The Competitive Advantage of European Nations: The Impact of National Culture-a Missing Component in Porter's Analysis? European Management Journal, 10(2), pp. 173-177.

Bellak, Christian A. and Andreas Weiss (1993). "A note on the Austrian "diamond", Management International Review, 33, 2, 109-118.

Berger, S. and R. K. Lester (1997). Made by Hong Kong, Oxford University Press, Hong Kong.

Brown, Gordon and Geoff Mulgan (1990). 'The Competitive Advantage of Nations by Porter, Michael E.', London Review of Books, 12, October 25, 10.

Carney, Mick (1991). 'The Competitive Advantage of Nations by Porter, Michael E.', RCSA/CJAS, 8, 4, 288-293

Cartwright, W.R. (1993). "Multiple linked "diamonds" and the international competitiveness of export-dependent industries: The New Zealand Experience', Management International Review, 2, $55-70$.

Caves, R. E., J. A. Frankel and R. W. Jones (1993), World Trade and Payments: An Introduction, Harper Collins, New York.

Cho, D-S. (1994). 'A dynamic approach to international competitiveness: The case of Korea,' Journal of Far Eastern Business, 1, 1, 17-36.

Clark, T. (1991). 'Review of the Competitive Advantage of Nations, by M. E. Porter', Journal of Marketing, October, 118-120.

Daly, D. J. (1993). 'Porter's Diamond and Exchange Rates', Management International Review, 2, 119-134.

\section{Copyrights}

Copyright for this article is retained by the author(s), with first publication rights granted to the journal. 